\title{
Isolation, Identification and Determination of the Absolute Configuration of Fischerellin B. A New Algicide from the Freshwater Cyanobacterium Fischerella muscicola (Thuret).
}

\author{
Ulrich Papkea ${ }^{a}$, Elisabeth M. Gross ${ }^{b}$ and Wittko Franckea*
}

\begin{abstract}
a: Universităt Hamburg, Institut fur Organische Chemie, Martin-Luther-King-Platz 6, 20146 Hamburg, Germany b: Max-Planck-Institut fur Limnologie, Abteilung fur Ökophysiologie, 24320 Pløn, Germany present address: Section of Ecology and Systematics, Cornell University, Ithaca, New York, USA 14853-2701
\end{abstract}

Konstanzer Online-Publikations-System (KOPS)

URL: http://www.ub.uni-konstanz.de/kops/volltexte/2008/4850/

URN: http://nbn-resolving.de/urn:nbn:de:bsz:352-opus-48508

\begin{abstract}
A new 2-pyrrolidinone with a polyunsaturated side chain has been identified from the cyanobacterium Fischerella muscicola (Thuret). Its structure was elucidated by UV, NMR and mass spectroscopy. Derivatisation of the natural product and stereocontrolled synthesis of the derivative allowed the determination of the absolute configuration by means of chiral gas chromatography. The new compound, fischerellin $B$, shows algicidal properties.
\end{abstract}

Recently the isolation of an algicide, fischerellin A, from the cyanobacterium Fischerella muscicola (Thuret) has been reported." Here we wish to report the isolation and structure determination of another algicide from this species, which could be isolated as a minor component and bioassayed as described previously. ${ }^{2}$ This new compound, which we like to call fischerellin B, is found in crude extracts in smaller quantities than fischerellin A. Similar to fischerellin A, fischerellin B is also present in F. ambigua (Näg.). ${ }^{2}$

The cyanobacteria were cultured and harvested as described earlier. ${ }^{2}$ Methanolic extracts of $70 \mathrm{~g}$ of lyophylised cyanobacteria were repeatedly subjected to RP-18-HPLC $\left(\mathrm{H}_{2} \mathrm{O} / \mathrm{MeOH}\right)$ followed by silica gel column chromatography $\left(\mathrm{Et}_{2} \mathrm{O}\right)$. The resulting yellowish solid (about $1 \mathrm{mg}$ ) was homogeneous by TLC, HPLC and GC. The compound was identified to be (3R,5S)-3-methyl-5-((5E)-pentadec-5-ene-7,9-diynyl)pyrrolidin-2-one (1). The identification procedure is described below.

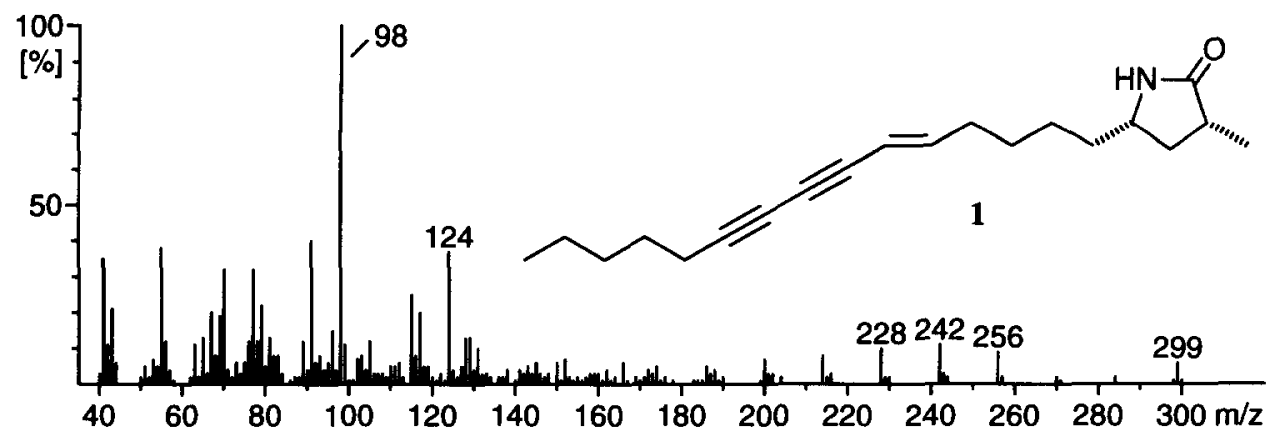


The mass spectrum obtained by GC-MS (Fisons MD 800 instrument) showed a molecular ion at $\mathrm{m} / \mathrm{z}=299$. High resolution MS (Fisons VG $250 \mathrm{SE}$ instrument) revealed the elemental composition to be $\mathrm{C}_{20} \mathrm{H}_{29} \mathrm{NO}$. The base peak of the spectrum at $\mathrm{m} / \mathrm{z}=98\left(\mathrm{C}_{5} \mathrm{H}_{8} \mathrm{NO}\right)$ suggested a methylated pyrrolidinone ring. ${ }^{3}$

The UV spectrum $(\mathrm{MeOH})$ showed a characteristic series of sharp absorptions at 240, 252, 267 and $283 \mathrm{~nm}$ indicating the presence of an enediyne chromophor. 4

Further information was obtained by one and two dimensional NMR spectroscopy. The results are summarised in Table 1.

Table 1. NMR spectroscopic Data of Fischerellin $B^{a}$

\begin{tabular}{|c|c|c|c|c|c|}
\hline Position & $\begin{array}{l}{ }^{13} \mathrm{C} \mathrm{Data}^{\mathrm{b}} \\
\delta[\mathrm{ppm}]\end{array}$ & $\begin{array}{l}{ }^{1} \mathrm{H} \text { Data } \\
\delta[\mathrm{ppm}], J[\mathrm{~Hz}]\end{array}$ & Position & $\begin{array}{c}{ }^{13} \mathrm{C} \text { Datab } \\
\delta[\mathrm{ppm}]\end{array}$ & $\begin{array}{l}\text { IH Data } \\
\delta[\mathrm{ppm}], J[\mathrm{~Hz}]\end{array}$ \\
\hline 1 & - & 6.38, bs & $4^{\prime}$ & 33.0 & $1.68, \mathrm{qd}, J_{4^{\prime}, 5^{\prime}}=J_{4^{\prime}, 3^{\prime}}=7.1$, \\
\hline 2 & 179.5 & - & & & $J_{4^{\prime}, 6^{\prime}}=1.4$ \\
\hline 3 & 36.9 & $\begin{array}{l}2.09, \mathrm{ddq}, J_{3,4 \mathrm{a}}=8.5, \\
J_{3}=10.5, J_{3}=7.1\end{array}$ & $\begin{array}{l}5^{\prime} \\
6^{\prime}\end{array}$ & $\begin{array}{l}147.5 \\
109.6\end{array}$ & $\begin{array}{l}6.13, \mathrm{dt}, J_{5^{\prime}, 6^{\prime}}=15.9 \\
5.41, \mathrm{dtt}, J_{6^{\prime}}=1.1\end{array}$ \\
\hline $4 a$ & 37.1 & $\begin{array}{l}1.74, \text { ddd, } J_{4 \mathrm{a}, 5}=6.2 \\
J_{4 \mathrm{a}, 4 \mathrm{~b}}=12.2\end{array}$ & $\begin{array}{l}7^{\prime} \\
8^{\prime} \\
9^{\prime}\end{array}$ & $\begin{array}{l}74.4 \\
74.6 \\
66.5\end{array}$ & $\begin{array}{l}- \\
- \\
-\end{array}$ \\
\hline 5 & 52.1 & $2.77-2.82, \mathrm{~m}$ & $10^{\prime}$ & 84.2 & - \\
\hline 3-Me & 16.3 & $1.16, \mathrm{~d}$ & $11^{\prime}$ & 19.6 & $1.97, \mathrm{dt}, J_{11: 12^{\prime}}=7.0$ \\
\hline $1^{\prime} \mathrm{a}$ & 36.7 & $0.92-1.00, \mathrm{~m}$ & $12^{\prime}$ & 28.2 & $1.22-1.29, \mathrm{~m}$ \\
\hline$l^{\prime} b$ & & $0.80-0.89, \mathrm{~m}$ & $13^{\prime}$ & 31.1 & $1.10-1.17, \mathrm{~m}$ \\
\hline $2^{\prime}$ & 25.3 & $0.77-0.85, \mathrm{~m}$ & $14^{\prime}$ & 22.3 & $1.03-1.11, \mathrm{~m}$ \\
\hline $3^{\prime}$ & 28.4 & $0.88-0.95, \mathrm{~m}$ & $15^{\prime}$ & 15.0 & $0.76, \mathrm{t}, J_{15^{\prime}, 14^{\prime}}=7.2$ \\
\hline
\end{tabular}

a: Bruker DRX-500 spectrometer, $\mathrm{C}_{6} \mathrm{D}_{6}$, chemical shifts referred to $\mathrm{C}_{6} \mathrm{D}_{5} \underline{\mathrm{H}}$ at $7.16 \mathrm{ppm}$ and $\underline{\mathrm{C}}_{6} \mathrm{D}_{6}$ at $128.0 \mathrm{ppm}$.

b: assignments based on $\left({ }^{1} \mathrm{H},{ }^{13} \mathrm{C}\right)-\mathrm{COSY}$ and $\mathrm{HMBC}$ experiments.

The ${ }^{13} \mathrm{C}$ NMR spectrum showed 20 signals representing two primary, nine secondary, four tertiary and five quaternary carbons as determined by a DEPT experiment. The signals of four quaternary carbons between 65 and $85 \mathrm{ppm}$ are in good agreement with the presence of two acetylenic bonds. ${ }^{5}$ The remaining quaternary signal appeared at $179.5 \mathrm{ppm}$ indicating a carbonyl carbon. Based on the elemental composition, this was regarded as part of an amide group. Furthermore, in the ${ }^{1} \mathrm{H}$ NMR spectrum the corresponding amide proton appeared at $6.38 \mathrm{ppm}$ as a broad singlet. Investigation of the connectivities by phase sensitive $\left({ }^{1} \mathrm{H},{ }^{1} \mathrm{H}\right)$-COSY experiments revealed a pyrrolidinone ring bearing a methyl group in 3-position and a side chain in 5-position. A NOESY experiment showed a NOE between $\mathrm{H}-3$ and $\mathrm{H}-5$ suggesting cis-configuration for the two substituents of the pyrrolidinone ring. This was supported by the relatively large difference in the shift values of $1.04 \mathrm{ppm}$ between the two protons of the diastereotopic methylene group in the ring, as shown for similar structures. ${ }^{6}$ The side chain consisted of four methylene groups followed by an olefinic bond, which, according to the ${ }^{1} \mathrm{H}$ NMR spectrum showed trans-geometry because of the large coupling constant of $15.9 \mathrm{~Hz}$ between the two olefinic protons at 5.41 and $6.13 \mathrm{ppm}$. In addition, a straight chain pentyl group was 
found to be present in the side chain. These two partial structures corresponded via a remarkably small coupling constant of $1.1 \mathrm{~Hz}$. As confirmed by a HMBC experiment this could be assigned to a long range coupling over seven bonds, which involves the diyne system connecting both parts.

Determination of the absolute configuration was carried out as follows: Ozonolysis of the natural product on a microgram scale ${ }^{7}$ followed by reduction resulted in selective cleavage of the double bond. Subsequent trifluoroacetylation yielded the two products 2 and 3, which were further analysed by GC-MS 8 (Scheme 1).

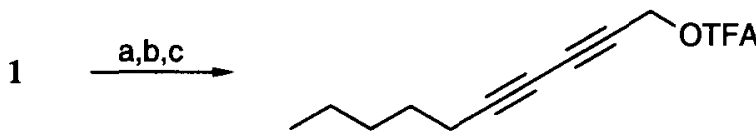

2

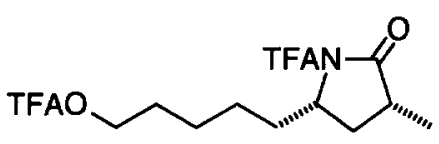

$(3 R, 5 S)-3$

Scheme 1

Reagents: a) $\mathrm{O}_{3}$, EtOAc, $-70^{\circ} \mathrm{C}, 60 \mathrm{~s}$; b) $\mathrm{NaBH}_{4}$, EtOAc, $1 \mathrm{~h}$; c) TFAA, EtOAc, $60^{\circ} \mathrm{C}, 1 \mathrm{~h}$.

All the four possible stereoisomers of 3 were prepared as shown for (3R,5S)-3 (Scheme 2). The stereocontrolled synthesis of the corresponding educts $(3 R, 5 R)-4$ and $(3 S, 5 R)-4$ from D-pyroglutamic acid as well as $(3 S, 5 S)-4$ and $(3 R, 5 S)-4$ from L-pyroglutamic acid has been recently described. 6 Tosylation to 5 and chain elongation yielded 6 . The appropriate cuprate was prepared by reaction of copper(I)bromidedimethylsulfide-complex with the Grignard reagent of benzylprotected 4-bromobutan-1-ol. Under the specified conditions the coupling reaction proceeded with a good yield, and the stereochemistry at C-3 remained untouched. Catalytic hydrogenation furnished debenzylated products 7,9 which upon trifluoroacetylation yielded the desired trifluoroacetates of the stereoisomers of 3.

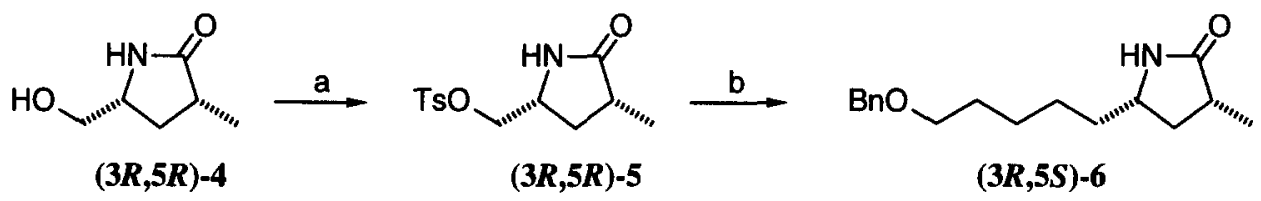<smiles>CCCCC[C@H]1C[C@H](C)C(=O)N1</smiles>

Scheme 2

Reagents: a) TsCl, DMAP, $\mathrm{NEt}_{3}, \mathrm{CH}_{2} \mathrm{Cl}_{2}, 20 \mathrm{~h}, 80 \%$; b) $\left(\mathrm{BnO}\left(\mathrm{CH}_{2}\right)_{4}\right)_{2} \mathrm{CuMgBr}$ (5 eq.), $\mathrm{Et}_{2} \mathrm{O} / \mathrm{DME},-78^{\circ} \mathrm{C}$, $22 \mathrm{~h}, 85 \%$; c) $\mathrm{H}_{2} / 10 \% \mathrm{Pd}-\mathrm{C}, \mathrm{MeOH}, 3.5 \mathrm{~h}, 95 \%$; d) excess TFAA, EtOAc, $60^{\circ} \mathrm{C}, 1 \mathrm{~h}$. 
Synthetic material and the derivative of the natural product exhibited identical mass spectra. Cis- and trans-isomers of 3 could be separated by GC on a standard apolar stationary phase (BPX-5; SGE Inc.). Coelution of the cis-isomers with the derivative of the natural product confirmed the relative configuration predicted by NMR spectroscopic investigation of 1 . The use of a 1:1 mixture of heptakis(2,6-di-O-methyl-3pentyl)- $\beta$-cyclodextrin and silicon OV-1701 (Macherey-Nagel) as a stationary phase allowed gaschromatographic separation of the two cis-enantiomers. Comparison of their retention times with 3 prepared from natural 1 proved the absolute configuration of fischerellin $\mathrm{B}$ to be $(3 R, 5 S)$.

Structural and possible biogenetic relations between fischerellin A and fischerellin B are quite obvious. While the polyunsaturated side chain in fischerellin $B$ is unbranched as confirmed by derivatisation and comparison with synthetic material, the structure of fischerellin $\mathrm{A}$ has been reported to show a methylbranching in the side chain. ${ }^{1}$

Unbranched compounds showing a conjugated enediyne substructure and an oxygene containing functional group at one end of the chain have been isolated from higher plants ${ }^{10}$ and, more recently, from marine sponges. 11

\section{REFERENCES AND NOTES}

1. Hagmann, L.; Jüttner, F. Tetrahedron Lett. 1996, 37, 6539-6542.

2. Gross, E. M.; Wolk, C. P.; Jüttner, F. J. Phycol. 1991, 27, 686-692.

3. Porter, Q. N. Mass Spectrometry of Heterocyclic Compounds; John Wiley and Sons, Inc.: New York, 1985; pp. 493-494.

4. Bohlmann, F.; Bornowski, H.; Arndt, C. Fortschr. Chem. Forsch. 1962, 4, 138-272.

5. Zeisberg, R.; Bohlmann, F. Chem. Ber. 1974, 107, 3800-3805.

6. Armstrong, R. W.; DeMattei, J. A.. Tetrahedron Lett. 1991, 32, 5749-5752

7. Attygalle, A. B.; Morgan, E. D. Angew. Chem. 1988, 100, 475-494; Angew. Chem. Int. Ed. Engl. 1988. 100, 460-479.

8. Compound 2: MS, m/z $231(5 \%), 190(11 \%), 149(9 \%), 131(15 \%), 117(68 \%), 103(63 \%), 91(86 \%)$, $77(76 \%), 69(68 \%), 63(45 \%), 55(100 \%), 50(38 \%), 41(70 \%)$.

Compound 3: MS, m/z $377\left(\mathrm{M}^{+}, 0.1 \%\right), 308$ (4\%), 264 (3\%), $236(2 \%), 194$ (100\%), $166(37 \%), 151$ (21\%), $96(11 \%), 81(13 \%), 69(48 \%), 55(19 \%), 41(29 \%)$.

9. (3R,5S)-7: $[\alpha]_{\mathrm{D}}^{20}+10.3^{\circ}\left(c 2.0, \mathrm{CHCl}_{3}\right) ;{ }^{1} \mathrm{H}-\mathrm{NMR}\left(500 \mathrm{MHz}, \mathrm{C}_{6} \mathrm{D}_{6}\right): \delta 0.83(1 \mathrm{H}, \mathrm{ddd}, J=8.9,10.7$ and $12.2 \mathrm{~Hz}, \mathrm{H}-4 \mathrm{a}), 1.10-1.64\left(8 \mathrm{H}, \mathrm{m}, \mathrm{H}-\mathrm{l}^{\prime}, \mathrm{H}-2^{\prime}, \mathrm{H}-3^{\prime}\right.$ and $\left.\mathrm{H}-4^{\prime}\right), 1.17$ (3H, d, $\left.J=7.1 \mathrm{~Hz}, 3-\mathrm{Me}\right), 1.79$ (1H, ddd, $J=6.6,8.4$, and $12.2 \mathrm{~Hz}, \mathrm{H}-4 \mathrm{~b}), 2.09-2.21(1 \mathrm{H}, \mathrm{m}, \mathrm{H}-3), 3.01-3.10(2 \mathrm{H}, \mathrm{m}, \mathrm{H}-5$ and $\mathrm{OH}$ ), 3.59-3.71 (2H, m, H-5'), 8.44 (1H, bs, NH), ${ }^{13} \mathrm{C}-\mathrm{NMR}$ (125 MHz, $\left.\mathrm{C}_{6} \mathrm{D}_{6}\right): 816.3$ (3-Me), 25.5 (C-3'), $25.8\left(\mathrm{C}-2^{\prime}\right), 33.0\left(\mathrm{C}^{\prime} 4^{\prime}\right), 37.2(\mathrm{C}-3), 37.2\left(\mathrm{C}^{\prime} 1^{\prime}\right), 37.3(\mathrm{C}-4), 52.6(\mathrm{C}-5), 61.7\left(\mathrm{C}-5^{\prime}\right), 181.7(\mathrm{C}-2)$

$(3 S, 5 S)-7:[\alpha]_{\mathrm{D}}^{20}+26.1^{\circ}\left(\mathrm{c} \mathrm{2.0}, \mathrm{CHCl}_{3}\right)$; ${ }^{1} \mathrm{H}-\mathrm{NMR}\left(500 \mathrm{MHz}, \mathrm{C}_{6} \mathrm{D}_{6}\right): \delta 1.00-1.63\left(10 \mathrm{H}, \mathrm{m}, \mathrm{H}-4, \mathrm{H}-1^{\prime}\right.$, H-2', H-3' and H-4'), $1.12(3 \mathrm{H}, \mathrm{d}, \mathrm{J}=7.1 \mathrm{~Hz}, 3-\mathrm{Me}), 2.21-2.33(1 \mathrm{H}, \mathrm{m}, \mathrm{H}-3), 2.95(1 \mathrm{H}, \mathrm{bs}, \mathrm{OH}), 3.12-$ $3.20(1 \mathrm{H}, \mathrm{m}, \mathrm{H}-5), 3.58-3.67\left(2 \mathrm{H}, \mathrm{m}, \mathrm{H}-5^{\prime}\right), 8.94(1 \mathrm{H}, \mathrm{bs}, \mathrm{NH}) .{ }^{13} \mathrm{C}-\mathrm{NMR}\left(125 \mathrm{MHz}, \mathrm{C}_{6} \mathrm{D}_{6}\right): \delta 16.5$ (3-Me), 25.3 (C-3'), 25.7 (C-2'), 33.1 (C-4'), 35.6 (C-3), 35.8 (C-4), 36.7 (C-1'), 52.0 (C-5), 61.6 (C5'), $181.6(\mathrm{C}-2)$.

10. Etse, J. T.; Waterman, P. G. Phytochem. 1986, 25, 1903-1905.

11. Barrow, R. A.; Capon, R. J. Aust. J. Chem. 1994, 47, 1901-1918. 